\title{
Global Crises: Gendered Vulnerabilities of Structural Inequality, Environmental Performance, and Modern Slavery
}

\author{
Erinn C. Cameron ${ }^{1}$ (D) . Samantha L. Hemingway ${ }^{1}$ (D) - Fiona J. Cunningham ${ }^{1}$ (D) \\ Kristine M. Jacquin ${ }^{2}$
}

Received: 17 July 2020 / Revised: 17 October 2020 / Accepted: 19 October 2020 /

Published online: 8 March 2021

(c) Springer Nature Switzerland AG 2021

\begin{abstract}
Climate change and modern slavery are two of the most significant human rights crises of our time. Women and children are disproportionately vulnerable to such crises, which are intensified under inequitable social conditions and driven by structural barriers to female equality. No research has yet looked at the complex relationship between climate crisis, structural gender inequality, human insecurity, and vulnerability to modern slavery. Our research examined the relationship between environmental stressors associated with climate change, selected structural inequalities, and the estimated prevalence of modern slavery cases across 180 countries. Regression analysis revealed significant results. These findings suggest that indicators of poor environmental health may exacerbate structural social inequalities and increase women's risk of falling victim to modern slavery. Results showed that women's share of seats in parliament, education for women, tree cover loss, agricultural management, and air quality assumed more substantial roles in this prediction. Awareness of the unique relationship between environmental indicators of climate change, gender inequality, and modern slavery provides a meaningful contribution to our understanding of factors driving human exploitation. Additionally, we propose a gender analysis of environmental stressors to address both the climate crisis and structural inequalities that increases female vulnerability to insecurity.
\end{abstract}

Keywords Human trafficking · Gender inequality · Modern slavery · Climate crisis · Human rights $\cdot$ Environmental performance index

The physical and psychological consequences of environmental crises and human exploitation disproportionately affect women, children, and economically disadvantaged individuals, resulting in profound social injustices that directly threaten the human rights and equity of the world's most vulnerable populations (Center for International Environmental

Erinn C. Cameron

ecameron@email.fielding.edu

1 Student in Clinical Psychology, School of Psychology, Fielding Graduate University, 2020 De La Vina St, Santa Barbara, CA 93105, USA

2 Psychology Department Chair and Professor of Psychology, School of Psychology, Fielding Graduate University, Santa Barbara, USA 
Law 2011; Human Rights and Equal Opportunity Commission 2008; United Nations Office of the High Commissioner for Human Rights 2014). The loss of food security, shelter, and personal safety frequently associated with waning environmental health and ecological vitality threaten the fundamental human rights embodied in the Universal Declaration of Human Rights (UDHR) (United Nations, 1948).

In accordance with the UDHR, all humans are inherently deserving of security and a standard of living suitable for health and well-being. An acceptable standard of living includes the right to adequate nutrition, clothing, housing, and medical care (United Nations, 1948). The consequences of environmental destruction additionally infringe on the economic, social, and cultural rights dictated by the International Covenant on Economic, Social, and Cultural rights, including the right of self-determination; the right to pursue economic, social, and cultural development; the right to "the highest attainable standard of physical and mental health"; and the right to education (The United Nations General Assembly [UNGA], 1966). From a constitutional standpoint, 118 nations globally maintain the right to a healthy environment in various articulations (Kravchenko, 2008).

\section{Climate Crisis as a Global Crisis}

Climate crisis refers to the devastating consequences of climate change driven by failing environmental health and ecosystem vitality faced by the world today. Described in 2018 by United Nations' Sec retary-General António Guterres as "the defining crisis of our time," declining environmental health and ecosystem vitality represents a transnational threat impacting every corner - and every citizen—of the world (United Nations Secretary-General 2018). The Lancet Countdown on health and climate change has warned that "a rapidly changing climate has dire implications for every aspect of human life, exposing vulnerable populations to extremes of weather, altering patterns of infectious disease, and compromising food security, safe drinking water, and clean air" (Watts et al., 2018). Direly, in the 2019 Global Environment Outlook, the United Nations reported that "nearly one-quarter of all deaths globally in 2012 could be attributed to modifiable environmental risks, with a greater portion occurring in populations in a vulnerable situation" (United Nations Environment, 2019, p. 22). Additionally, the World Health Organization (WHO) correspondingly states that $23 \%$ of all deaths in 2012, representing 12.6 million people, were the result of living or working in an unhealthy environment (WHO 2016). Further, research indicates that diverse environmental indicators, including anthropogenic effects such as climate change, have significantly contributed to the global human disease burden (Prüss-Ustün et al., 2017).

\section{Environmental Indicators of Climate Crises}

The most readily observable consequences of environmental effects on human health are evident in changes in the composition of the atmosphere, the growing accumulation of greenhouse gases, and the effects such changes have on bodies of land, ocean, and ice (World Meteorological Organization 2020). One measurement used for ascertaining environmental health and ecosystem vitality is the 2018 Environmental Performance Index (EPI; Wendling et al. 2018). Developed by researchers at Yale and Columbia universities and the World Economic Forum, the EPI is used to assesses environmental sustainability and policy and ranks 180 countries on 24 performance indicators across ten issues 
categories: air quality; water and sanitation; heavy metals; biodiversity and habitat; forests; fisheries; climate and energy; air pollution; water resources; and agriculture (Wendling et al. 2018). The 10 issue categories evaluated by the EPI represent environmental stressors associated with climate change with researchers noting that countries with lower EPI scores are often those that also experience problems such as weak governance and civil unrest (Wendling et al. 2020). The EPI 2018 also indicates that air quality is currently the most significant environmental threat to public health (Wendling et al. 2020).

\section{Climate Crisis, Human Insecurity and Displacement}

Equally as important as the environmental consequences of climate crisis are the social consequences of climate crisis. Alterations in global weather patterns, including changing rainfall patterns and the increasing emergence of extreme weather events, continue to adversely affect food and habitation security (World Meteorological Association 2020). Rising global temperatures and variability in seasonal rains increasingly contribute to the loss and damage of agricultural lands and crop yields worldwide (Shukla et al. 2019). Between 2006 and 2016 alone, an estimated 26\% of the economic costs of climate-related disasters incurred in developing countries were the result of loss or damage of agriculture, primarily in the forms of crops and livestock. Further, climate variability and weather extremes have been shown to be both leading drivers and compounding factors in the recent rise in global hunger (Food and Agriculture Organization of the United Nations 2019).

In addition to driving food shortages and fueling an impending severe global hunger crisis, natural disasters and extreme weather events are responsible for the displacement of millions of individuals. In 2019 alone, more than 23.9 million people were displaced as the result of nearly 1,900 weather-related disasters occurring across 140 countries and territories (Internal Displacement Monitoring Center 2020). The scope and severity of 2019 weather-related displacements are borne out in the statistics: 3.4 million new displacements in Sub-Saharan Africa in response to cyclones Idai and Kenneth and widespread flooding; 9.6 million new displacements in East Asia and the Pacific as a result of monsoons and typhoons; 631,000 new disaster displacements in the Middle East and North Africa; 9.5 million new displacements in South Asia due to floods, monsoons, and cyclones Fani and Bulbul; and 1.5 million new displacements in North and South America primarily due to flooding (Internal Displacement Monitoring Center 2020).

Although most individuals displaced as a result of climate and disaster-related events remain within their country of origin, displacement across borders is also a common occurrence (Thompson 2019). International displacement, sometimes referred to as forced or involuntary migration, may be one of the few options available to displaced individuals, particularly if the reason for displacement affects an entire country or other large geographical areas (Thompson 2019). A recent example of international displacement can be witnessed in the thousands of Somali refugees who have fled to Ethiopia in response to the loss of crops, livestock die-offs, and famine induced by severe drought (Nguyen 2019).

\section{Environmental Crises and Human Exploitation}

Be it international or intranational, both forced and voluntary migration are frequently associated with environmental changes and interrelated with conflict and violence (Berlemann and Steinhardt, 2017; Thompson 2019). While displaced individuals of all genders are at increased risk of victimization, migrant women and girls, in particular, are frequently 
the target of violence, harassment, sexual abuse, and sexual and labor exploitation (Banford and Froude 2015; Beneria et al. 2012; Danailova-Trainor and Laczko, 2010; Nobre et al., 2019). Women and girls often suffer most in temporary housing, lacking proper infrastructure (Nobre et al. 2019). Unsafe living environments, such as those characteristic of refugee camps, "tent cities," and transitory settlements, place women and girls at greater risk of being victimized by human traffickers (United Nations 2016).

The United Nations defines human trafficking as "the recruitment, transportation, transfer, harboring, or receipt of persons by improper means (such as force, abduction, fraud, or coercion) for an improper purpose including forced labor or sexual exploitation" (United Nations Office on Drugs and Crimes [UNODC] 2016a). While there is no universally acknowledged definition, "trafficking in persons," "human trafficking," and "modern slavery" are umbrella terms used to refer to all forms of coerced exploitation, including sex trafficking, forced organ donation, forced marriage, and all forms of compelled labor (Craig et al. 2019; Walk Free Foundation [WFF] 2018). These terms will be used interchangeably throughout this manuscript.

Human trafficking is a global human rights crisis, with an estimated 40.3 million victims worldwide (International Labour Organization 2018; WFF 2018). Of these 40.3 million victims, 23.8 million are victims of sexual trafficking, and 14.9 million are exploited via non-sexual forced labor or domestic servitude (UNODC 2018a). Women and girls constitute a disproportionate majority of all trafficking victims (71\%) and an overwhelming majority (99\%) of sex trafficking victims (UNODC, 2018a; WFF 2018).

\section{Human Trafficking as a Human Rights Crisis}

Victims of human trafficking suffer severe physical and psychological consequences due to the prolonged and interpersonal nature of the abuse, such as complex posttraumatic stress disorder, dissociation, shame, and stigma (Hossain et al. 2010; Iglesia-Rios et al. 2018; Jina and Thomas 2013; Katona et al. 2015; Meng et al. 2016; Oram et al. 2012). The act of human trafficking itself, as well as the consequences borne of the act, violate the fundamental human rights embodied in the UDHR, such as the right to freedom from slavery and servitude, and the right to safety and security (United Nations Office of the High Commissioner for Human Rights 2014; United Nations,1948). Specifically, the UDHR affirms, "no one shall be held in slavery or servitude; slavery and the slave trade shall be prohibited in all their forms" (United Nations, 1948). As human rights are universal, all victims of trafficking are entitled to the full breadth of fundamental human rights and protections set forth by the United Nations and upheld by international law, regardless of sex, gender, age, race, ethnicity, nationality, citizenship, migratory status, or other distinction. By this definition alone, modern slavery, like climate change, is a global human rights crisis demanding the immediate attention of all governing bodies.

\section{Climate Crises and Structural Gender Inequality}

Environmental risk factors are further compounded by economic stressors and social inequities that traditionally place women in the line of violence and exploitation. Environmental stressors that lead to a scarcity of resources, such as loss of crop yields and livestock, and prompt migration are known correlates of increased rates of physical violence and adverse health outcomes (Banford and Froude 2015; McMichael, 2015; Memon, 2020; Otto et al., 2017; Rezaeian, 2013). Similarly, a substantial body of research has provided 
strong evidence that poverty and economic migration are foundational push factors for human trafficking (Aronowitz 2009; Cameron and Newman 2008; Cameron et al. 2019b; Cho 2015; David et al., 2019; Gjermeni et al. 2008; Noyori-Corbett and Moxley 2016; Rao and Prestini 2012; United Nations Children's Fund 2005; World Bank Group 2017).

\section{Climate Change and Gender Inequality}

Research has indicated that women are disproportionately vulnerable to human trafficking and the negative consequences of climate change, both of which are intensified under inequitable social conditions driving gender inequality (Arora-Jonsson 2011; Enarson 2012; Cameron et al. 2019b, 2020; Fisher, 2010; Heckenberg and Johnston, 2012; Sidun and Flores 2020; Tomkins et al. 2018; Walby et al. 2016). Structural barriers to female equality include women's inability to access resources independently, limited influence on decision-making processes, unequal educational opportunities, the feminization of poverty, and high rates of violent gender-based victimization (Cameron et al. 2019b; Enarson 2012; Felten-Biermann 2006; Melo 2019; Okech et al. 2018; Parkinson and Zara 2013; Sety et al. 2014; Sidun and Flores 2020; True 2016). Also, stereotyped social and cultural roles may prevent women and girls from learning essential survival skills (Nguyen 2018). Additionally, research indicates that women are more vulnerable to the effects of climate change than men, especially women in the global South (Arora-Jonsson 2011), the same region with the lowest scores on the EPI Index (Wendling et al. 2020).

Additionally, over $88 \%$ of the global disease burden attributable to climate change occurs in children younger than five years of age (Sheffield and Landrigan, 2011). A robust body of literature documents the detrimental effects of climate change trauma in pediatric populations, such as increased susceptibility to disease, stunting due to nutritional deficiencies, psychological problems, substance use, and sleep disorders (Bartlett 2008; Bunyavanich et al. 2003; Dyregrov et al. 2018; McDermott and Cobham 2012; Perera 2017). As the majority of responsibility for childcare is assumed by women and girls, particularly those that are poor and vulnerable, the obligation to care for sick and ailing children falls traditionally to the mother or other female family member (Samman et al. 2016). As childcare is both time- and resource-intensive, women and girls burdened with the inequitable division of care are inhibited from advancing in other areas of their lives. According to the Overseas Development Institute (Samman et al. 2016), "care responsibilities not only reduce possibilities for female education and inhibit labour force participation, they also affect the types of jobs women do, how productive they are and how much they earn" (p. 9).

\section{Psychological Consequences of Climate Crises}

The psychological consequences of crises are often overlooked in consideration of the immediate and long-term physical effects of climate change factors and human exploitation. However, the mental health consequences of exposure to diverse traumatic stressors have been well documented across global populations, highlighting that whether due to natural or human-made events, psychological responses to trauma are similar (American Psychological Association 2008; Bonanno et al. 2010; McFarlane and Van Hooff 2014; Parslow et al. 2006). Further, the environmental factors contributing to climate change are often anthropogenic and thus can be considered as both natural and human-made.

Extreme weather events and natural disasters can trigger psychological problems such as posttraumatic stress disorder (PTSD), major depressive disorder, anxiety, depression, 
complicated grief, survivor guilt, vicarious trauma, recovery fatigue, substance abuse, and suicidal ideation (American Psychological Association 2014; Beaglehole et al. 2018; Doherty and Clayton 2011; WHO 2015; Willox et al. 2015). Populations that are already vulnerable and marginalized, frequently women and children, assume the majority burden of mental and physical health effects of climate-related trauma and stressors (WHO 2015). Sex and gender differences in the development of psychiatric disorders demonstrate that women are two to three times more likely to develop PTSD following a traumatic experience compared to men (American Psychiatric Association 2013; Olff 2017). Similar differences between genders have also been observed in the development of comorbid disorders of anxiety disorders and major depression (American Psychiatric Association 2013), suggesting that women may be disproportionately vulnerable to the detrimental psychological consequences of weather-related disasters and climate-related stressors.

\section{Psychological Consequences of Human Exploitation}

In addition to the already-mentioned psychological consequences of climate crises, victims of human trafficking can face additional, specific effects of trauma (Abas et al. 2013; Katona et al. 2015; Meng et al. 2016; Zimmerman and Kiss, 2017 ). Unlike severe weather events or natural disasters, human trafficking has interpersonal intentionality that creates an additional layer of psychological trauma (Hossain et al. 2010; Iglesia-Rios et al. 2018; Park 2016). For example, complex PTSD can occur after prolonged, repeated experiences of interpersonal trauma, specifically in a context where the individual has little or no chance of escape (Abas et al. 2013).

Further, in some countries, the stigma associated with sex trafficking can be reinforced by legal systems that criminalize prostitution (Contreras et al. 2017). Sex trafficking can also lead to health outcomes such as HIV/AIDS and substance abuse, which is associated with further stigma. It is important to note that general risk factors for PTSD include being female, having a lower education level, and having preexisting mental health conditions (McFarlane and Van Hooff 2014; Meng et al. 2016; Parslow et al. 2006), all of which are also commonly seen in victims of exploitative activities such as trafficking.

\section{Study Rationale}

Past research has addressed both macro- and micro-level contributors to human trafficking, with studies indicating that structural inequality and gendered violence against women play a significant role in increasing women's vulnerability to trafficking (Bales 2007; Barner et al. 2014; Cameron et al. 2019a; 2019b; Cho 2015; Heath and Jayachandra 2016; Melo 2019; Okech et al. 2018; Sidun and Flores 2020). Additionally, studies have indicated that women and girls are disproportionately vulnerable to both human trafficking and the negative consequences of climate change, which is intensified under inequitable social conditions (Arora-Jonsson 2011; Cameron et al. 2019b; Enarson 2012; Noyori-Corbett and Moxley et al. 2016; Sidun and Flores 2020; Tomkins et al. 2018). However, no research has yet looked at the complex relationship between environmental indicators related to climate change, structural inequality, and human insecurity as evidence of increased vulnerability to modern slavery. We posit that there is an important association between the effects of climate change and structural inequality and the cultural roles assigned to women and children, which further contributes to complex vulnerability. We hypothesized that specific 
indicators of environmental stressors associated with climate change and structural inequality would be associated with increased vulnerability to modern slavery victimization.

\section{Method}

Public archival data sets were used. Indicators of structural inequality were obtained from the United Nations Development Program (UNDP; (2019b) and the UNODC (2018a). Indicators of climate change were obtained as part of the framework of the 2018 EPI (Wendling et al. 2018). Data regarding the estimated prevalence of modern slavery was obtained from the 2018 Global Slavery Index (WFF 2018).

\section{Indicators of Structural Gender Inequality}

Indicators of structural gender inequality were chosen based on the human rights framework established in the United Nations 2015 Sustainable Development Goals, with specific consideration given to indicators of extreme poverty and hunger, universal primary education, and gender equality and empowerment of women (United Nations Statistics Division (UNSTATS) 2019). Data for the predictors of structural gender inequality were obtained from the UNDP (2019b). Five selected structural gender inequality indicators were included in this study, percentage of women ( 25 and older) with some secondary education, mean years of schooling for women, share of seats in parliament for women, labour force participation rate for women ages 15 years and above, and estimated gross national income for women.

\section{Indicators of Environmental Stressors Associated with Climate Change}

The EPI (Wendling et al. 2018) is a method of quantifying environmental performance, defined as environmental health and ecosystem vitality of a state's policies, and was developed within the framework of the environmental goals proposed in the United Nations 2015 Sustainable Development Goals (UNSTATS 2019) and the Paris Climate Agreement (United Nations Framework Convention on Climate Change 2015). The 2018 EPI includes scores for 24 performance indicators across 10 issue categories for 180 countries. All 10 issue categories were used in our analysis, including air quality, water and sanitation, heavy metals, biodiversity and habitat, forests, fisheries, climate and energy, air pollution, water resources, and agriculture. Issue categories track performance and progress on two broad policy objectives of environmental health, and ecosystem vitality (Wendling et al. 2018). See Fig. 1 for the specific variables that comprise the 10 issue categories of the 2018 EPI. Comprehensive information regarding the $2018 \mathrm{EPI}$ can be found at https://epi.envirocenter.yale.edu/.

\section{Estimated Prevalence of Modern Slavery}

The 2018 Global Slavery Index (WFF 2018) provides an estimate of the number of people currently victimized by modern slavery across 198 countries. Estimates are comprised of the subestimates of forced labor and forced marriage. Forced labor was further conceptualized as forced labor occurring in the private economy, forced sexual exploitation, and state-imposed forced labor. A more detailed explanation of how 


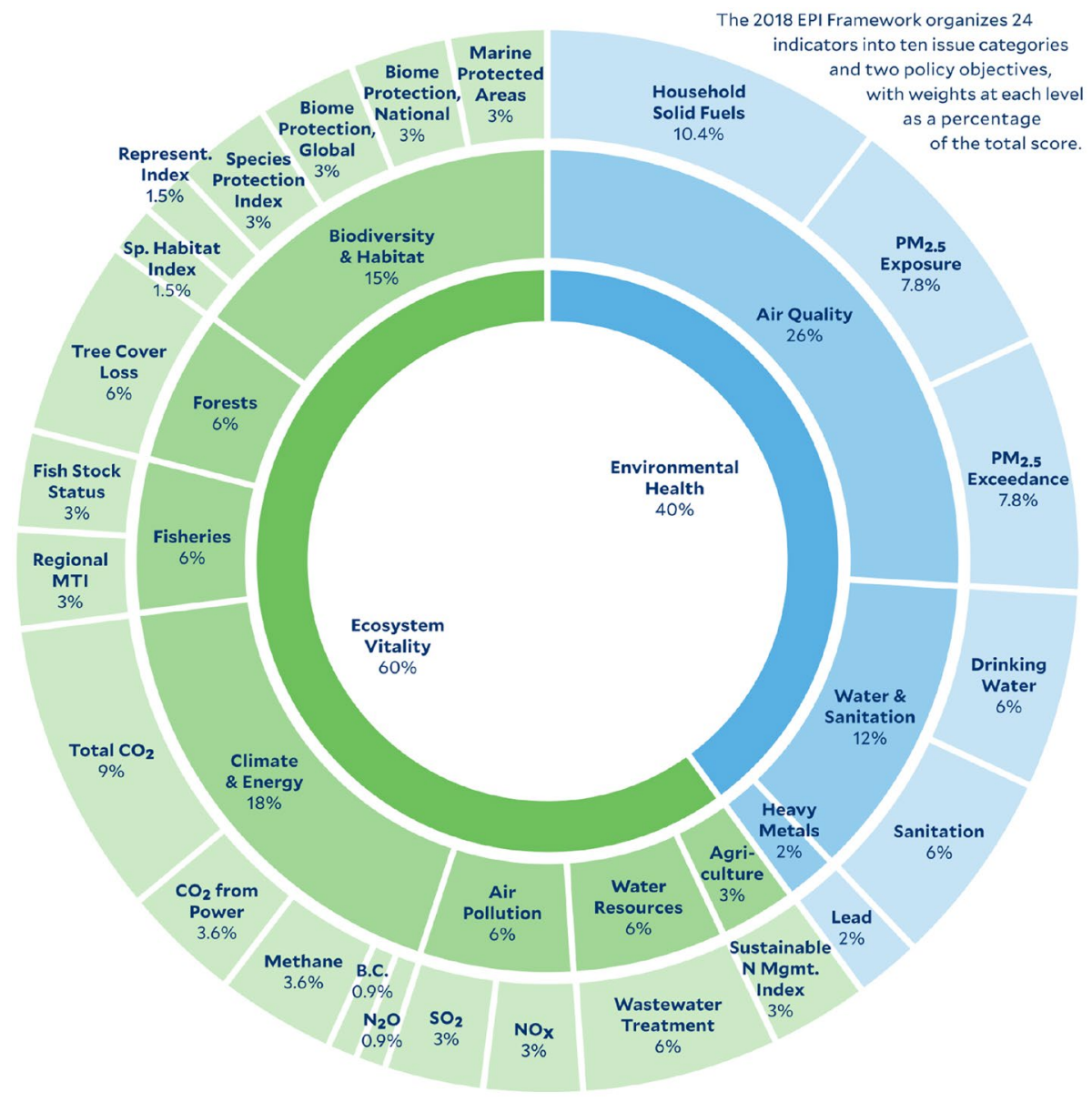

Fig. 1 The 2018 EPI framework

modern slavery estimates were calculated for the Global Slavery Index 2018 can be found at https://www.globalslaveryindex.org/about/the-index/.

\section{Procedure}

Data sets from the UNODC (2019a), UNDP (2019b), 2018 EPI (Wendling et al. 2018), and the 2018 Global Slavery Index (WFF 2018) were combined. Regression analysis with backward removal was used to analyze the predictive ability of specific indicators of structural gender inequality and environmental stressors associated with climate change in relation to the estimated prevalence of modern slavery victims across countries. 


\section{Results}

A correlation analysis was conducted to examine the relationships between independent and dependent variables (see Table 1). Regression analysis with backward removal was used to test the hypothesis and find the best model of indicators of structural gender inequality and environmental stressors associated with climate change that predict the estimated prevalence of modern slavery victims (per 1000 in the population) across countries. The assumptions of normality, homoscedasticity, linearity, and absence of multicollinearity were met.

All models were significant at $p<0.001$. The full model $(F(15,75)=4.924, p<0.001$, adj. $\left.R^{2}=0.40\right)$ contained the ten environmental indicators of water and sanitation, agriculture-sustainable nitrogen management, climate and energy, air quality, forests-tree cover loss, biodiversity and habitat, heavy metals-lead exposure, water resources-wastewater treatment, air pollution, and fisheries. The five predictors of structural gender inequality in the full model were labor force participation rate percentage for females $15+$, the share of seats in parliament for women, percentage of females 25+ with some secondary education, estimated gross national income per capita females, and mean years schooling females. This model predicted $40 \%$ of the variance in the estimated prevalence of modern slavery victims across countries. The results of the backward regression analysis for the full model with $\mathrm{t}$-scores and beta weights can be found in Table 2 .

The final model (model 11) achieved the largest effect size, $F(1,84)=15.581$, $p<0.001$, adj. $R^{2}=0.45$ and contained three climate change predictors: agriculture-sustainable nitrogen management, air quality, and forests-tree cover loss; and two structural gender inequality indicators, the share of seats in parliament for women, and percentage of females $25+$ with some secondary education. This set of predictors predicted $45 \%$ of the estimated prevalence of modern slavery across countries. Table 3 represents the predictors from model 11. Both sets of results were consistent with our hypothesis that specific indicators of structural gender inequality and environmental stressors associated with climate change would significantly predict the estimated prevalence of modern slavery.

Beta values indicate relationships between variables and compare the strength of the effect of each individual predictor and the criterion variable. In the full model, the strongest beta values of the climate change predictors were tree cover loss $(\beta=0.41)$ and air quality $(\beta=-0.21)$, and both were correlated with the estimated prevalence of modern slavery as predicted. As expected, all of the gender inequality predictors except for labour force participation rate for women were negatively correlated with the estimated prevalence of modern slavery. Labor force participation rate for women was positively correlated with the estimated prevalence of modern slavery. The beta values of the final and most significant model were consistent with the values seen in the full model.

\section{Discussion}

We hypothesized that specific indicators of environmental stressors associated with climate change and structural gender inequality would be associated with increased vulnerability to modern slavery victimization. While the entire model was significant, certain indicators of climate change and structural inequality played a larger role than others in predicting the estimated prevalence of modern slavery victims, such as secondary education for women 


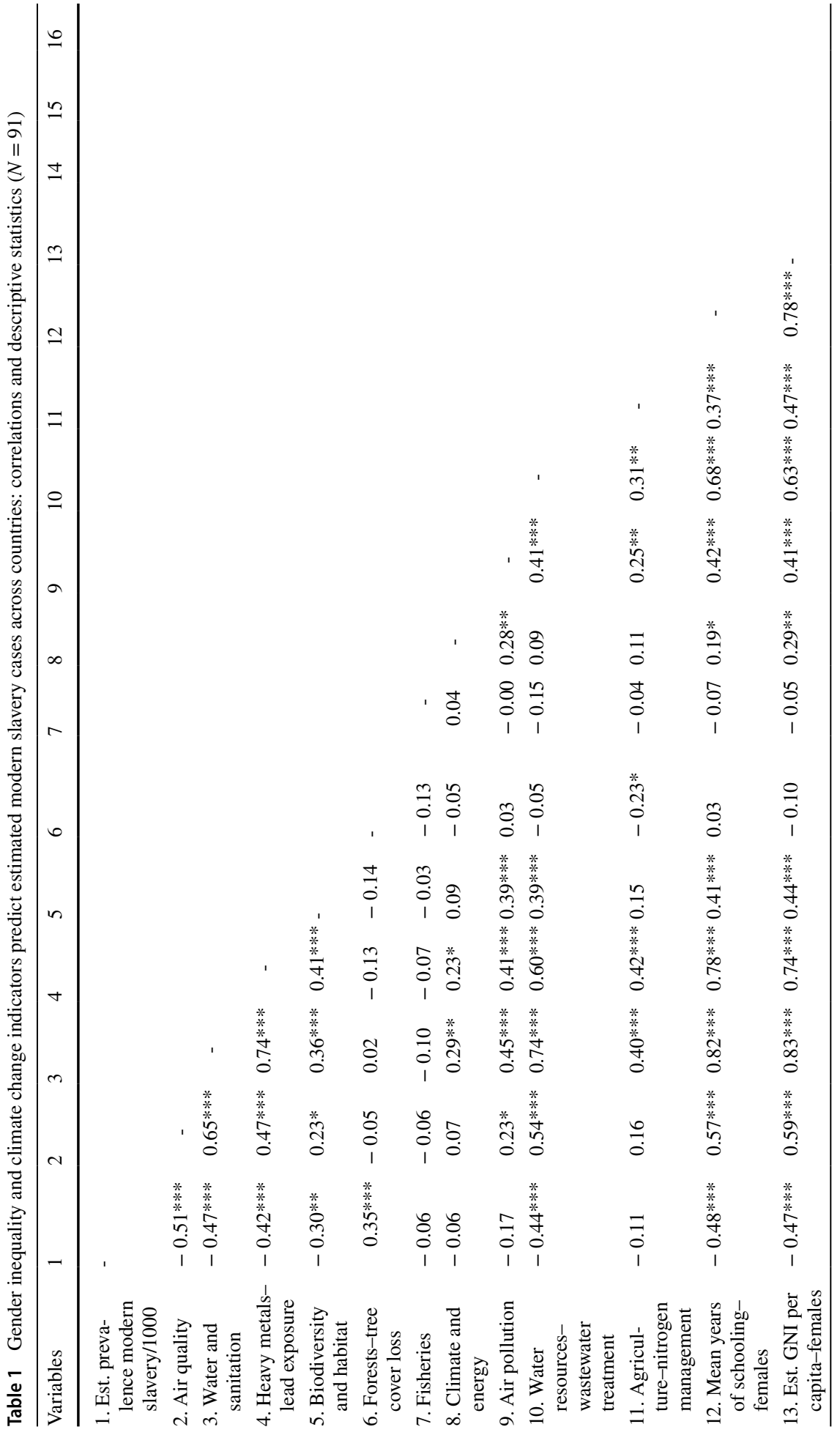




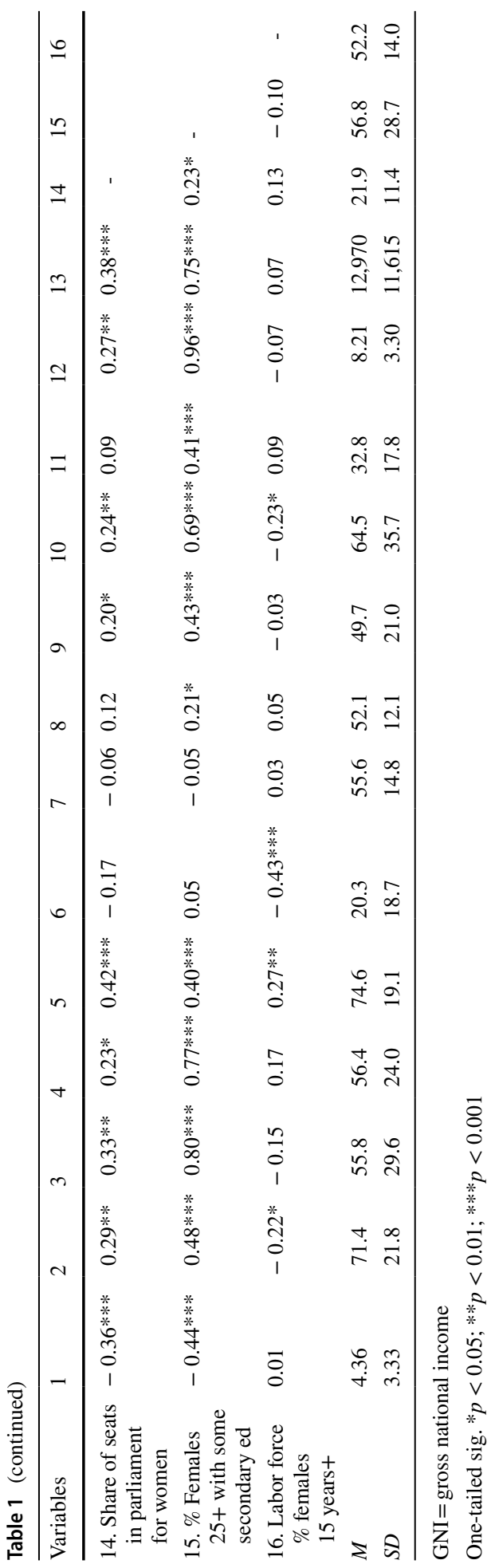


Table 2 Results of the backward regression analysis for the full model

\begin{tabular}{|c|c|c|c|c|c|c|}
\hline Variables in full model & $t$ & $\beta$ & $F$ & $d f$ & $p$ & Adj. $R^{2}$ \\
\hline Overall model & & & 4.92 & 15,75 & $<0.001$ & 0.40 \\
\hline \multicolumn{7}{|l|}{ Climate change indicators } \\
\hline Air quality & 0.35 & -0.21 & & & & \\
\hline Air pollution & -1.70 & 0.04 & & & & \\
\hline Fisheries & -0.67 & -0.06 & & & & \\
\hline Agriculture & 1.90 & 0.19 & & & & \\
\hline Climate and energy & 0.60 & 0.06 & & & & \\
\hline Forests & 4.02 & 0.41 & & & & \\
\hline Biodiversity and habitat & -0.23 & -0.02 & & & & \\
\hline Heavy metals & -0.04 & -0.01 & & & & \\
\hline Wastewater resources & -0.19 & -0.03 & & & & \\
\hline Water and sanitation & -0.24 & -0.05 & & & & \\
\hline \multicolumn{7}{|l|}{ Gender inequality indicators } \\
\hline Share of seats in parliament & -1.46 & -0.14 & & & & \\
\hline$\%$ Females $25+$ with secondary education & -0.43 & -0.14 & & & & \\
\hline Mean years schooling (females) & -0.50 & -0.16 & & & & \\
\hline Est. GNI per capita (females) & -0.44 & -0.08 & & & & \\
\hline Labor force participation rate & 0.95 & 0.11 & & & & \\
\hline
\end{tabular}

over the age of 25, the number of seats in parliament for women, tree cover loss, agricultural management, and air quality. Additionally, we propose that due to the disproportional effects of climate change and human exploitation on women and girls, a gender and sexbased analysis should be a crucial component of all recommendations and interventions within a human rights-based framework.

\section{Forest Management}

The final model identified tree cover loss $(\beta=0.38)$ as one of the strongest significant predictors of modern slavery when considered within the context of the other predictors in the

Table 3 Results of the backward regression analysis for the final model

\begin{tabular}{lllllll}
\hline Variables in the final model & $t$ & $\beta$ & $F$ & $d f$ & $p$ & Adj.R $^{2}$ \\
\hline Overall model & & & 15.581 & 1,84 & $<0.001$ & 0.45 \\
Climate change indicators & & & & & \\
$\quad$ Air quality & -3.59 & -0.31 & & & \\
$\quad$ Agriculture & 2.09 & 0.19 & & & \\
$\quad$ Forests & 4.51 & 0.38 & & \\
Gender inequality indicators & & & & \\
$\quad \begin{array}{l}\text { Share of seats in parliament } \\
\quad \text { \% Females 25+ with secondary }\end{array}$ & -3.56 & -0.35 & & & \\
$\quad$ education & & & & \\
\hline
\end{tabular}


model. This facet of forest management represents a significant human rights issue as forests are integral to human quality of life. About 1.6 billion people worldwide rely on forest ecosystems as their source of income, and approximately 300 million people live in forests including more than 60 million indigenous people (Resource Watch, 2020). Further, tree cover is inextricably linked to key environmental systems that are related to human security such as the water cycle, soil health, climate, and air quality.

\section{Agricultural Management}

The agricultural management predictor $(\beta=0.19)$ refers to the sustainable nitrogen management index, which measures the Euclidean distance from an ideal point with optimal nitrogen use efficiency (NUE) and crop yield (Oenema et al. 2015; Wendling et al. 2018). Increasing a plant's ability to utilize nitrogen efficiently is an important consideration for environmental sustainability and food security. Unsustainable agricultural practices are one of the most significant causes of global food scarcity, which has been linked to forced migration (Morales-Muñoz et al. 2020). According to the United Nations, about 690 million people are undernourished worldwide, and by 2050 that number is expected to increase by an additional two billion people (Food and Agriculture Organizations of the United Nations et al., 2019). Additionally, increased food insecurity and threat of widespread famine are being driven by the current COVID-19 pandemic, which has emphasized existing inequalities and vulnerabilities (Smith and Wesselbaum 2020). While the optimization of crop production and NUE is a complex problem, greater NUE values are generally indicative of increased crop yields (Oenema et al. 2015). While a yield increase may contribute to increased food security, it also drives the need for more labor. An estimated $42 \%$ of trafficking victims are trafficked within their country of origin (UNODC 2018a), and the estimates that there are about 3.5 million people worldwide who currently work under forced labor conditions in the agricultural industry.

\section{Air Quality}

The EPI 2018 air quality predictor $(\beta=-0.31)$ refers to household solid fuels, $\mathrm{PM}_{2.5}{ }^{1}$ exposure, and $\mathrm{PM}_{2.5}$ exceedance. Household air pollution has been identified as a significant human factor in the climate crisis, and factors related to household cooking technology are a major source of household air pollution across the globe (Boyd et al. 2019). Approximately three billion people continue to depend on solid fuels for cooking and heating (WHO) including the majority of rural sub-Saharan Africa (Boyd et al. 2019; Pachauri et al. 2012). Solid fuels are typically utilized with poorly ventilated traditional indoor cooking and heating methods that use open fires and inefficient stoves, such as with the traditional Injera baking stove in Ethiopia (Adane et al. 2020). Traditionally, women and young children experience the highest exposure levels from household air pollution due to food preparation and household management being customary household roles (Amegah and Jaakkola, 2016; Pachauri and Rao 2013; Perera 2017; WHO). A human-rights approach to improving air quality must include innovative solutions for introducing safe, environmentally sound household cooking and heating options, which will also contribute

1 "Particulate matter with an aerodynamic diameter of $2.5 \mu \mathrm{m}$ or less" (WHO, 2020). 
to reducing vulnerability to exploitation for already marginalized populations across the globe.

\section{Education for Women}

Results indicated that percentage of women (25 and older) with some secondary education had an inverse relationship with the estimated prevalence of modern slavery across countries $(\beta=-0.146)$. As established by the United Nations human rights framework, women's education is a key indicator of gender parity (UNDP 2016a; UNSD 2019). Gender stereotypes that suggest women are intellectually inferior to men commonly drive the exclusion of women from traditionally male-dominated fields of study such as science and technology, as well as other forms of higher education (Razavi \& Turquet, 2016). Lacking educational opportunities comparable to their male counterparts, women are frequently consigned to "unskilled" domestic, household, and childcare work. As a result, women are over-represented in low or unpaid occupations, placing them at a significant socioeconomic disadvantage. The feminization of poverty, combined with the hardships and dangers of displacement and migration, place women at increasingly escalated risk of exploitation (Cameron et al. 2019a; Melo 2019; Olubukola 2020). Additionally, research has demonstrated the association between human trafficking and lack of education for women (Cameron et al. 2020).

\section{Share in Seats of Parliament for Women}

Results indicated that the share of seats in parliament for women $(\beta=-0.15)$ had an inverse relationship with the estimated prevalence of modern slavery across countries, indicating that the lack of women in critical governing bodies may increase women's vulnerability to trafficking. Studies have noted that political exclusion increases women's vulnerability to adverse experiences overall (Davies and True 2017) and where women have higher levels of rights and increased representation in government human trafficking laws are more likely to be enforced (Cho et al. 2014). Further, when women's participation in leadership is limited, human rights issues that directly affect females are not as commonly addressed, which may result in increased victimization by traffickers (Razavi and Turquet 2016). These results were not unexpected and highlight the urgent need for women to obtain equal rights and representation in decision making at national levels.

\section{Water and Sanitation}

While not represented in the final model, water and sanitation was significant in the full model $(\beta=-0.25)$ and should be part of a gender and sex-based analysis due to its importance within a human rights framework that addresses gender inequality. Access to clean water is at the very core of human adaptation to environmental stressors and climate change, serving as a crucial link between society and the environment, and is a major human rights consideration (United Nations 2020). Statistics show that it is mainly women and children who are affected by the unsafe management of human waste (United Nations Educational, Scientific and Cultural Organization 2017) and that 1 in 3 people globally do not have access to clean drinking water. 
Further, according to the WHO (2019), water and sanitation-related diseases remain among the major causes of deaths worldwide for children in the under-five age group. Also, in many cultures, women and children are primarily responsible for managing household water supplies, which is integral to sanitation and health for families. Additionally, household water management includes water procurement, which can be a time consuming, challenging, and sometimes even dangerous chore for women and girls (Pommells et al. 2018). The global water crisis has been referred to as a "women's crisis" (Water.org 2020). Furthermore, access to clean and safe water is crucial for individuals who have menstruation and maternity needs (United Nations 2020). These sex-specific needs and gendered responsibilities can have harmful effects on school participation, health and disease management, and other components of a safe, productive, and healthy life for women and children across cultures.

\section{Recommendations}

In alignment with past research, we argue that strict anti-trafficking policies have not been sufficient to combat the egregious human rights crisis of modern slavery. Additionally, current climate agreements have been inadequate to solve the growing climate crisis. Instead, policies and actions that are in alignment with the United Nations' Sustainable Development Goals and that address structural gender inequalities and climate change, as well as the specific predictors in our model, are needed. Targeted and culturally appropriate interventions, novel technologies, solutions, and further analysis are needed to prevent and control emerging physical and mental health threats associated with the interaction between environmental stressors associated with climate change, structural gender inequality, and modern slavery. Additionally, public health interventions are needed to target the needs of climate refugees, especially during migration, to minimize associated risks such as vulnerability to human trafficking.

Further, to provide appropriate physical and mental health care (prevention, screening, and treatment) for victims of climate crises and human trafficking, assessments and interventions should address possible chronic conditions, mental health problems, and trauma symptoms. A trauma-informed approach to all forms of care is crucial for addressing the effects of trauma due to the associated consequences of climate crises, such as migration, economic insecurity, food insecurity, disease, physical injury, and exploitation.

Additionally, for mental health professionals, the complex factors that contribute to the psychological consequences of trauma that can result from modern slavery victimization can be challenging to treat (Abas et al. 2013; Katona et al. 2015). The age and stage at which the victim experiences the trauma, the victim's relationship to the perpetrator, duration of the trauma, and available support system can all contribute to treatment difficulty (Abas et al. 2013; Courtois 2004; Meng et al. 2016). Identification of the mental health problems that can result from the intersecting and complex consequences of modern slavery, climate change, and structural gender inequality is a crucial initial step to developing appropriate diagnostic, treatment, and support options for victims.

Studies have indicated sex-specific psychological effects of trauma, yet research into the impact of human trafficking across sex or gender is in its infancy (Iglesias-Rios et al. 2018; 2019; O'Donnell et al. 2017). Additionally, Iglesias-Rios et al. (2019) noted that sex differences in experienced violence and coercion among trafficking victims could have 
important implications for mental health symptomology, providing further evidence for the necessity of gender-informed treatment.

\section{Limitations}

Data regarding the estimated prevalence of modern slavery victims was provided by the 2018 Global Slavery Index (WFF 2018), which has no definitive way to ensure standardization of reporting procedures across governing bodies. Limitations associated with this estimate include variations in definitions of trafficking crimes and trafficking laws between countries, which may result in inconsistent reporting of data. Countries may vary widely in their consideration of what constitutes human trafficking. Further, not all countries have clear trafficking legislation or may have varying cultural factors that may influence legislation. Also, the UNODC (2018) reports that even when countries with clear legislation collect trafficking data, there is often no centralized authoritarian source responsible for data collection, storage, processing, or reporting. Instead, statistics reported to the United Nations may come from incongruent sources (e.g., police; public prosecutors; individual, local, or state government agencies; non-governmental organizations), which rarely collaborate on their efforts (Aronowitz 2010; UNODC 2018). Additionally, the GSI examines estimated prevalence of modern slavery within a country and does not distinguish between intranational and international victims of exploitation. Therefore, distinguishing factors cannot be drawn between these two populations. Also, limitations at the predictor level include not only variations in data collection procedures across countries but also incongruous definitions. For example, many measures of NUE define production as a function of inputs such that given constant inputs; any yield increase would be reflected in greater NUE values. However, studies have indicated that NUE is operationalized differently across countries, with unstandardized parameters for data collection (Oenema et al. 2015).

\section{Conclusion}

Our findings suggest that specific indicators of environmental stress associated with climate change may exacerbate structural social inequalities and increase vulnerability to modern slavery. When examined together, environmental predictors of air quality and agricultural management, and gender inequality indicators of women's share of seats in parliament and percentage of women over the age of 25 with secondary education, were found to play a particularly large role in increasing vulnerability. Awareness of the relationship between environmental stressors, gender inequality, and modern slavery provides a meaningful contribution to our understanding of factors driving human exploitation and provides an empirical foundation for recommendations and interventions that serve to ameliorate the causes and consequences of climate crisis and modern slavery that are associated with human suffering.

With a burgeoning recognition of the role of climate change in human exploitation, antitrafficking efforts should seek to address underlying environmental and ecological conditions that contribute to women and girls' heightened vulnerability. Concurrently, anti-trafficking efforts must continue to combat existing gender inequalities repeatedly shown to be at the very heart of the modern slavery trade. Until theses contributors are addressed, climate change and extreme weather events will continue to adversely affect food and 
habitation security, driving food shortages and mass displacement, and heightening the vulnerability of millions of people to the risk of violent victimization and exploitation.

\section{Availability of Data and Material}

Publicly available archival data.

\section{Compliance with Ethical Standards}

Conflict of Interest The authors declare that they have no conflicts of interest.

\section{References}

Abas, M., Ostrovschi, N., Prince, M., Gorceag, V., Trigub, C., Oram, S. et al. Risk factors for mental disorders in women survivors of human trafficking: A historical cohort study. BMC Psychiatry, 13(1). https://doi.org/10.1186/1471-244X-13-204

Adane, M. M., Alene, G. D., Mereta, S. T., Wanyonyi, K. L. et al. (2020). Prevalence and risk factors of acute lower respiratory infection among children living in biomass fuel using households: A community-based cross-sectional study in northwest Ethiopia. BMC Public Health, 20(1). https://doi. org/10.1186/s12889-020-08515-w

Amegah, A. K., \& Jaakkola, J. J. (2016). Household air pollution and the sustainable development goals. Bulletin of the World Health Organization, 94(3), 215-221. https://doi.org/10.2471/blt.15.155812

American Psychiatric Association (2013). Diagnostic and statistical manual of mental disorders (5th ed.). https://doi.org/10.1176/appi.books.9780890425596

American Psychological Association (2008). Catastrophic disasters: Federal efforts help states prepare for and respond to psychological consequences, but FEMA's crisis counseling program needs improvements [Data set]. https://doi.org/10.1037/e431192008-001

American Psychological Association. (2014). Report from APA and ecoAmerica examines psychological impacts of climate change. PsycEXTRA Dataset. https://doi.org/10.1037/e577792014-003

Aronowitz, A. (2010). Overcoming the challenges to accurately measuring the phenomenon of human trafficking. Revue internationale de droit pénal, 81(3), 493-511. https://doi.org/10.3917/ridp.813.0493

Aronowitz, A. A. (2009). The smuggling - trafficking nexus and the myths surrounding human trafficking. Immigration, Crime, and Justice, 7-128,. https://doi.org/10.1108/s1521-6136(2009)0000013010

Arora-Jonsson, S. (2011). Virtue and vulnerability: Discourses on women, gender and climate change. Global Environmental Change, 21(2), 744-751. https://doi.org/10.1016/j.gloenvcha.2011.01.005

Bales, K. (2007). What predicts human trafficking? International Journal of Comparative and Applied Criminal Justice, 31(2), 269-279. https://doi.org/10.1080/01924036.2007.9678771

Banford, A., \& Froude, C. K. (2015). Ecofeminism and natural disasters: Sri Lankan women post-tsunami. Journal of International Women's Studies, 16(2), 170-187. https://doi.org/10.1177/1077801210377649

Barner, J. R., Okech, D., Camp, M. A. et al. (2014). Socioeconomic inequality, human trafficking, and the global slave trade. Societies, 4(2), 148-160. https://doi.org/10.3390/soc4020148

Bartlett, S. (2008). Climate change and urban children: Impacts and implications for adaptation in low- and middle-income countries. Environment and Urbanization, 20(2), 501-519. https://doi. org/10.1177/0956247808096125

Beaglehole, B., Mulder, R. T., Frampton, C. M., Boden, J. M., Newton-Howes, G., Bell, C. J., et al. (2018). Psychological distress and psychiatric disorder after natural disasters: Systematic review and metaanalysis. The British Journal of Psychiatry, 213(6), 716-722. https://pubmed-ncbi-nlm-nih-gov.fgul. idm.oclc.org/30301477/

Benería, L., Deere, C. D., Kabeer, N. et al. (2012). Gender and international migration: Globalization, development and governance. Feminist Economics, 18(2), 1-33. https://doi.org/10.1080/13545701.2012.688998 
Berlemann, M., \& Steinhardt, M. F. (2017). Climate change, natural disasters, and migration-A survey of the empirical evidence. CESifo Economic Studies, 63(4), 353-385. https://doi.org/10.1093/cesifo/ if $\mathrm{x} 019$

Bonanno, G. A., Brewin, C. R., Kaniasty, K., Greca, A. M. L. et al. (2010). Weighing the costs of disaster: Consequences, risks, and resilience in individuals, families, and communities. Psychological Science in the Public Interest, 11(1), 1-49. https://doi.org/10.1177/1529100610387086

Boyd, D. R. (2019). The human right to breathe clean air. Annals of Global Health, 85(1). https://doi. org/10.5334/aogh.2646

Bunyavanich, S., Landrigan, C. P., McMichael, A. J., Epstein, P. R. et al. (2003). The impact of climate change on child health. Ambulatory Pediatrics, 3(1), 44-52. https://doi.org/10.1367/15394409(2003)003\%3c0044:tiocco\%3e2.0.co;2

Cameron, E. C, Cunningham, F. J, Hemingway, S. L., Jacquin, K. M. et al. (2019a, May 23-26). Indicators of women's health inequality predict estimated modern slavery cases across countries [Poster]. $31^{\text {st }}$ Association of Psychological Science Annual Convention, Washington, D.C. https://www.psychologicalscience. org/conventions/archive/2019-2

Cameron, E. C., Cunningham, F. J., Hemingway, S. L., Tschida, S. L.,Jacquin, K.M. (2020). Human development indicators predict human-trafficking legal cases. The Journal of Human Trafficking https://doi. org/10.1080/23322705.2020.1852000

Cameron, E. C, Hemingway, S. L., Jacquin, K. M. et al. (2019b, June 11-15). Gender inequality, female migration, and violence against women as predictors of modern slavery across UN countries [Poster]. International Council of Psychologists 77th Annual Conference, Cadiz, Spain. https://icpweb. org/2019-conference-cadiz-spain/

Cameron, S., \& Newman, E. (2008). Trafficking in humans: Structural factors. In Trafficking in humans: Social, cultural and political dimensions (pp. 21-57). https://ebookcentral-proquest-com.fgul.idm. oclc.org

Center for International Environmental Law. (2011). Climate change \& human rights: A primer. http:// www.ciel.org/Publications/CC_HRE_23May11.pdf

Cho, S. (2015). Modeling for determinants of human trafficking: An empirical analysis. Social Inclusion, 3(1), 2-21. https://doi.org/10.17645/si.v3i1.125

Cho, S. Y., Dreher, A., Neumayer, E. et al. (2014). Determinants of anti-trafficking policies: Evidence from a new index. The Scandinavian Journal of Economics, 116(2), 429-454. https://doi-org.fgul.idm.oclc. org/10.1111/sjoe. 12055

Contreras, P. M., Kallivayalil, D., Herman, J. L., et al. (2017). Psychotherapy in the aftermath of human trafficking: Working through the consequences of psychological coercion. Women \& Therapy, 40(1-2), 31-54. https://doi.org/10.1080/02703149.2016.1205908

Courtois, C. A. (2004). Complex trauma, complex reactions: Assessment and treatment. Psychotherapy: Theory, Research, Practice, Training, 41, 412-425.

Craig, G., Balch, A., Lewis, H., Waite, L. et al. (2019). Editorial introduction: The modern slavery agenda: Policy, politics and practice. In G. Craig, A. Balch, H. Lewis, \& L. Waite (Eds.), The modern slavery agenda: Policy, politics and practice, 1-28. Polity Press.

Danailova-Trainor, G., \& Laczko, F. (2010). Trafficking in persons and development: Towards greater policy coherence. International Migration, 48(4), 38-83. https://doi.org/10.1111/j.1468-2435.2010.00625.x

David, F., Bryant, K., \& Larsen, J. J. (2019). Migrants and their vulnerability to human trafficking, modern slavery, and forced labour. International Organization for Migration. https://publications.iom.int/ system/files/pdf/migrants_and_their_vulnerability.pdf

Davies, S. E., \& True, J. (2017). The politics of counting and reporting conflict-related sexual and genderbased violence: The case of Myanmar. International Feminist Journal of Politics, 19(1), 4-21. https:// doi.org/10.1080/14616742.2017.1282321

Doherty, T. J., \& Clayton, S. (2011). The psychological impacts of global climate change. American Psychologist, 66(4), 265-276. https://doi.org/10.1037/a0023141

Dyregrov, A., Yule, W., Olff, M., et al. (2018). Children and natural disasters. European Journal of Psychotraumatology, 9(sup2), 1500823. https://doi.org/10.1080/20008198.2018.1500823

Enarson, E. P. (2012). Women confronting natural disaster: From vulnerability to resilience. Lynne Rienner Publishers.

Felten-Biermann, C. (2006). Gender and natural disaster: Sexualized violence and the tsunami. Development, 49(3), 82-86. https://doi.org/10.1057/palgrave.development.1100276

Fisher, S. (2010). Violence against women and natural disasters: Findings from post-tsunami Sri Lanka. Violence Against Women, 16(8), 902-918. https://doi.org/10.1177/1077801210377649 
Food and Agriculture Organization of the United Nations (2019). The state of food and agriculture 2019: Moving forward on food loss and waste reduction. Rome. Licence: CC BY-NC-SA 3.0 IGO. https:// www.fao.org/3/CA6030EN/CA6030EN.pdf

Gjermeni, E., Van Hook, M. P., Gjipali, S., Xhillari, L., Lungu, F., \& Hazizi, A. (2008). Trafficking of children in Albania: Patterns of recruitment and reintegration. Child Abuse \& Neglect, 32, 941-948.

Heath, R., \& Jayachandran, S. (2016). The causes and consequences of increased female education and labor force participation in developing countries (No. w22766). National Bureau of Economic Research. https://doi.org/10.3386/w22766

Heckenberg, D., \& Johnston, I. (2012). Climate change, gender and natural disasters: Social differences and environment-related victimisation. In Climate change from a criminological perspective (pp. 149171). Springer, New York, NY.

Hossain, M., Zimmerman, C., Abas, M., Light, M., Watts, C., et al. (2010). The relationship of trauma to mental disorders among trafficked and sexually exploited girls and women. American Journal of Public Health, 100(12), 2442-2449. https://doi.org/10.2105/AJPH.2009.173229

Human Rights and Equal Opportunity Commission. (2008). Human rights and climate change. HREOC. https://www.ohchr.org/Documents/Issues/ClimateChange/Submissions/Australia HR_ Equal_Opportunity_Commission_HR_ClimateChange_4.pdf

Iglesias-Rios, L., Harlow, S. D., Burgard, S. A., Kiss, L., Zimmerman, C. et al. (2018). Mental health, violence and psychological coercion among female and male trafficking survivors in the Greater Mekong sub-Region: A cross-sectional study. BMC Psychology, 6(1). https://doi.org/10.1186/s40359018-0269-5

Iglesias-Rios, L., Harlow, S. D., Burgard, S. A., West, B., Kiss, L., Zimmerman, C. et al. 2019 Patterns of violence and coercion with mental health among female and male trafficking survivors: A latent class analysis with mixture models. Epidemiology and Psychiatric Sciences 29. https://doi.org/10.1017/ s2045796019000295

Internal Displacement Monitoring Center/Norwegian Refugee Council (2020). Global report on internal displacement 2019. https://www.internal-displacement.org/global-report/grid2020/

International Labour Organization (2018). International labour organization statistics database (ILOSTAT). https://www.ilo.org/ilostat/

Jina, R., \& Thomas, L. S. (2013). Health consequences of sexual violence against women. Best Practice \& Research Clinical Obstetrics \& Gynaecology, 27(1), 15-26. https://doi.org/10.1016/j.bpobgyn. 2012.08.012

Katona, C., Robjant, K., Shapcott, R., Witkin, R. et al. (2015). Addressing mental health needs in survivors of modern slavery, A critical review and research agenda. Helen Bamber Foundation. https://freedomfund. org/wp-content/uploads/2015-Addressing-the-Mental-Health-Needs-in-Survivors-of-ModernSlavery.pdf

Kravchenko, S. (2008). Right to carbon or right to life: Human rights approaches to climate change. Vermont Journal of Environmental Law, 9, 513-547. https://doi.org/10.2139/ssrn.1304844

McDermott, B., \& Cobham, V. (2012). A road less travelled: A guide to children, emotions and disasters. South Brisbane Press

McFarlane, A. C., Van Hooff, M., et al. (2014). Learning for the future: The challenge of disaster research. Australian \& New Zealand Journal of Psychiatry, 48(7), 600-602. https://doi.org/10.1177/ 0004867414539236

McMichael, C. (2015). Climate change-related migration and infectious disease. Virulence, 6(6), 548-553. https:// doi.org/10.1080/21505594.2015.1021539

Melo, C. L. (2019). The feminization of poverty. Witness: The Canadian Journal of Critical Nursing Discourse, 1(1), 73-81. https://doi.org/10.25071/2291-5796.6

Memon, F. S. (2020). Climate Change and Violence Against Women: Study of A Flood-Affected Population in The Rural Area of Sindh, Pakistan. Pakistan Journal of Women's Studies: Alam-e-Niswan, 27, 65-85.

Meng, L., Jiang, J., Jin, C., Liu, J., Zhao, Y., Wang, W., et al. (2016). Trauma-specific grey matter alterations in PTSD. Scientific Reports, 6, 33748. https://doi.org/10.1038/srep33748

Morales-Muñoz, H., Jha, S., Bonatti, M., Alff, H., Kurtenbach, S., Sieber, S., et al. (2020). Exploring connections-Environmental change, food security and violence as drivers of migration-A critical review of research. Sustainability, 12(14), 5702. https://doi.org/10.3390/su12145702

Nguyen, H. T. (2018). Gendered vulnerabilities in times of natural disasters: Male-to-female violence in the Philippines in the aftermath of super typhoon Haiyan. Violence Against Women, 25(4), 421.

Nguyen, K. (2019). As drought compounds security woes, Somalis flee to Ethiopia. United Nations High Commissioner for Refugees. https:/www.unhcr.org/en-us/news/stories/2019/9/5d8495984/droughtcompounds-security-woes-somalis-flee-ethiopia.html 
Nobre, G. G., Peters,K., Mayhew, L., Guttieres, D., Cruz, J. I., Saccoccia, L., Kerins, P., Kumza, S. et al. (2019). Migration and displacement risks: Connecting dots, understanding trends. https://www.preventionweb. net/files/66268_f333guimaraesnobreetal migrationandd.pdf

Noyori-Corbett, C., \& Moxley, D. P. (2016). Inequality of women as a factor influencing migration from countries of origin to the United States and its implications for understanding human trafficking. International Social Work, 59(6), 890-903. https://doi.org/10.1177/0020872815580047

O’Donnell, M. L., Schaefer, I., Varker, T., Kartal, D., Forbes, D., Bryant, R. A., et al. (2017). A systematic review of person-centered approaches to investigating patterns of trauma exposure. Clinical Psychology Review, 57, 208-225. https://doi.org/10.1016/j.cpr.2017.08.009

Oenema O., Brentrup, F., Lammel, J., Bascou, P., Billen, G., Dobermann, A., Erisman, J.W., Garnett, T.,Hammel, M., Haniotis, T., Hillier, J., Hoxha, A., Jensen, L.S., Oleszek, W., Pallière, C., Powlson, D., Quemada, M., Schulman, M., Sutton, M.A., Van Grinsven, H., Winiwarter W. et al. (2015). Nitrogen Use Efficiency (NUE) - An indicator for the utilization of nitrogen in agriculture and food systems. EU Nitrogen Expert Panel. https://www.eunep.com/wp-content/ uploads/2017/03/Report-NUE-Indicator-Nitrogen-Expert-Panel-18-12-2015.pdf

Okech, D., Choi, Y. J., Elkins, J., Burns, A. C. et al. (2018). Seventeen years of human trafficking research in social work: A review of the literature. Journal of Evidence-Informed Social Work, 15(2), 103-122. https://doi.org/10.1080/23761407.2017.1415177

Olff, M. (2017). Sex and gender differences in post-traumatic stress disorder: An update. European Journal of Psychotraumatology, 8(sup4), 1351204. https://doi.org/10.1080/20008198.2017.1351204

Olubukola, I. A. (2020). Human trafficking in Edo State, Nigeria: Experiences of some young girls who have survived trafficking. Lwati: A Journal of Contemporary Research, 17(2), 204-224.

Oram, S., Stöckl, H., Busza, J., Howard, L. M., Zimmerman, C., et al. (2012). Prevalence and risk of violence and the physical, mental, and sexual health problems associated with human trafficking: Systematic review. PLoS Med, 9(5), e1001224. https://doi.org/10.1371/journal.pmed.1001224

Otto, I. M., Reckien, D., Reyer, C. P. O., Marcus, Rachel, Le Masson, Virginie, Jones, Lindsey, et al. (2017). Social vulnerability to climate change: a review of concepts and evidence. Regional Environmental Change, 17, 1651-1662.

Pachauri, S., \& Rao, N. D. (2013). Gender impacts and determinants of energy poverty: are we asking the right questions? Current Opinion in Environmental Sustainability, 5, 205-215.

Pachauri, S., Rao, N. D., Nagai, Y., Riahi, K. et al. (2012). Access to modern energy: Assessment and outlook for developing and emerging regions. http://pure.iiasa.ac.at/id/eprint/10145/1/XO-12-030.pdf

Park, C. L. (2016). Meaning Making in the Context of Disasters. Journal of Clinical Psychology, 72(12), 1234-1246.

Parkinson, D., \& Zara, C. (2013). The hidden disaster: Domestic violence in the aftermath of natural disaster. Australian Journal of Emergency Management, $28(2), 28$.

Parslow, R. A., Jorm, A. F., Christensen, H. et al. (2006). Associations of pre-trauma attributes and trauma exposure with screening positive for PTSD: Analysis of a community-based study of 2085 young adults. Psychological Medicine, 36(3), 387-395. https://doi.org/10.1017/S0033291705006306

Perera, F. P. (2017). Multiple threats to child health from fossil fuel combustion: Impacts of air pollution and climate change. Environmental Health Perspectives, 125(2), 141-148. https://doi.org/10.1289/ ehp299

Pommells, M., Schuster-Wallace, C., Watt, S., Mulawa, Z., et al. (2018). Gender violence as a water, sanitation, and hygiene risk: Uncovering violence against women and girls as it pertains to poor wash access. Violence Against Women, 24(15), 1851-1862. https://doi.org/10.1177/1077801218754410

Prüss-Ustün, A., Wolf, J., Corvalán, C., Neville, T., Bos, R., Neira, M. et al. (2017). Diseases due to unhealthy environments: an updated estimate of the global burden of disease attributable to environmental determinants of health. Journal of Public Health, 39(3), 464-475. https://doi. org/10.1093/pubmed/fdw085

Rao, S., \& Presenti, C. (2012). Understanding Human Trafficking Origin: A Cross-Country Empirical Analysis. Feminist Economics, 18, 231-263.

Razavi, S., \& Turquet, L. (2016). Progress of the world's women 2015-2016: Transforming economies, realizing rights. Global Social Policy, 16(1), 86-93. https://doi.org/10.1177/1468018115624314

Resourcewatch (2020). The world's forests. https://resourcewatch.org/dashboards/forests

Rezaeian, M. (2013). The association between natural disasters and violence: A systematic review of the literature and a call for more epidemiological studies. Journal of research in medical sciences: Journal of Isfahan University of Medical Sciences, 18(12), 1103.

Samman, E., Presler-Marshall, E., Jones, N., Bhatkal, T.,Melamed, C., Stavropoulou, M., Wallane, J. et al. (2016). Women's work: Mothers, children and the global childcare crisis. Oversees 
Development Institute. https://www.odi.org/sites/odi.org.uk/files/odi-assets/publications-opinionfiles/10333.pdf

Sety, M., James, K., Breckenridge, J. et al. (2014). Understanding the risk of domestic violence during and post natural disasters: Literature review. In Issues of gender and sexual orientation in humanitarian emergencies (pp. 99-111). Springer, Cham.

Sheffield, P. E., \& Landrigan, P. J. (2011). Global climate change and children's health: Threats and strategies for prevention. Environmental Health Perspectives, 119(3), 291-298. https://doi.org/10.1289/ ehp. 1002233

Shukla, P. R., Skea, J., Calvo Buendia, E., Masson-Delmotte, V., Pörtner, H. O., Roberts, D. C., Zhai, P., Slade, R., Connors, S., van Diemen, R., Ferrat, M., Haughey, E., Luz, S., Neogi, S., Pathak, M., Petzold, J., Portugal Pereira, J., Vyas, P., Huntley, E., Malley, J. et al. (Eds.). (2019). Climate change and land: An IPCC special report on climate change, desertification, land degradation, sustainable land management, food security, and greenhouse gas fluxes in terrestrial ecosystems. Intergovernmental Panel of Climate Change. https://www.ipcc.ch/srccl/

Sidun, N.M. \& Flores, Y.G. (2020). Human trafficking of women and girls: Inequality and increased risks. Rubin, N.S. \& Flores, R.L. (eds). The Cambridge Handbook of Psychology and Human Rights. Cambridge.

Smith, M. D., \& Wesselbaum, D. (2020). COVID-19, food insecurity, and migration. The Journal of Nutrition, 1-4. https://doi.org/10.1093/jn/nxaa270.

The United Nations General Assembly. (1966). International Covenant on Economic, Social, and Cultural Rights. Treaty Series, 999, 171.

Thompson, B. (2019). Climate change and displacement: How conflict and climate change form a toxic combination that drives people from their homes. Office of United Nations High Commissioner for Refugees. https://www.unhcr.org/news/stories/2019/10/5da5e18c4/climate-change-and-displacement.html

Tomkins, S., Farnadi, G., Amanatullah, B., Getoor, L., Minton, S. et al. (2018). The impact of environmental stressors on human trafficking. In 2018 IEEE International Conference on Data Mining (ICDM) (pp. 507-516). IEEE.

True, J. (2016). Gendered violence in natural disasters: Learning from New Orleans, Haiti and Christchurch. Aotearoa New Zealand Social Work, 25(2), 78-89. https://doi.org/10.11157/anzswj-vol25iss2id83

United Nations. (1948). Universal declaration of human rights. https://www.ohchr.org/EN/UDHR/Documents/ UDHR_Translations/eng.pdf

United Nations (2016). The sustainable development goals and migrants/migration, Version 3. https://www. un.org/en/development/desa/population/migration/events/coordination/14/documents/backgrounddocs/ GMPA_14CM.pdf

United Nations (2020). Peace, dignity, and equality on a healthy planet: Water. https://www.un.org/en/ sections/issues-depth/water/

United Nations Children Fund (2005). The state of the world's children 2006: Excluded and invisible summary. Oxford University Press for UNICEF. https://www.unicef.org/sowc06/pdfs/sowc06_fullreport. pdf

United Nations Development Programme (UNDP) (2019a). Human development report 2019: Human development for everyone. https://hdr.undp.org/sites/default/files/hdr2019.pdf

United Nations Development Programme (UNDP) (2019b). Human development reports: Human development data (1990-2019). https://hdr.undp.org/en/data

United Nations Educational, Scientific and Cultural Organization (2017). UIS Statistics. https://data.uis. unesco.org

United Nations Environment (2019). Global environment outlook - GEO-6: Summary for policymakers. Cambridge University Press.

United Nations Framework Convention on Climate Change (2015). The Paris climate agreement. https:// unfccc.int/files/essential_background/convention/application/pdf/english_paris_agreement.pdf

United Nations Office on Drugs and Crime (2018). Human trafficking. https://www.unodc.org/unodc/en/ human-trafficking/what-ishuman-trafficking.html

United Nations Office of the High Commissioner for Human Rights (2014). Women's rights are human rights, $H R / P U B / 14 / 2$. www.ohchr.org

United Nations Office of Drugs and Crime (2018a). Global report on trafficking in persons 2018. https:// www.unodc.org/documents/data-and-analysis/glotip/2018/GLOTiP_2018_BOOK_web_small.pdf

United Nations Office of Drugs and Crime (2018b). Human trafficking knowledge portal. https:// sherloc.unodc.org/cld/en/v3/htms/index.html

United Nations Office on Drugs and Crime (2016a). UNODC Statistics Online. https://data.unodc.org 
United Nations Office on Drugs and Crime (2016b). Global report on trafficking in persons 2016. https:// www.unodc.org/documents/data-and-analysis/glotip/2016_Global_Report_on_Trafficking_in_ Persons.pdf

United Nations Secretary-General (2018). Secretary-General's remarks on climate change [as delivered]. https://www.un.org/en/un75/climate-crisis-race-we-can-win

United Nations Statistics Division (2019). The sustainable development goals report. https://unstats.un.org/ sdgs/report/2019/The-Sustainable-Development-Goals-Report-2019.pdf

Walby, S., Apitzsch, B., Armstrong, J. E., Balderston, S., Szmagalska-Follis, K., Francis, B. J., Kelly, L., May-Chahal, C. A., Rashid, A., Shire, K., Towers, Tunte, M. et al. (2016). Study on the gender dimension of trafficking in human beings: Final report. Publications Office of the European Union. https://eprints.lancs.ac.uk/78779/1/study_on_the_gender_dimension_of_trafficking_in_human_ beings._final_report.pdf

Walk Free Foundation (2018). Global Slavery Index report. https://www.globalslaveryindex.org/ resources/downloads/

Water.org (2020). The water crisis: A women's crisis. https://water.org/our-impact/water-crisis/ womens-crisis/

Watts, N., Amann, M., Arnell, N., Ayeb-Karlsson, S., Belesova, K., Berry, H., et al. (2018). The 2018 report of the lancet countdown on health and climate change: Shaping the health of nations for centuries to come (executive summary). The Lancet, 392(10163), 2479-2514. https://doi. org/10.1016/S0140-6736(18)32594-7

Wendling, Z. A., Emerson, J. W., de Sherbinin, A., Esty, D. C. et al. (2020). Environmental Performance Index. Yale Center for Environmental Law \& Policy. https://epi.yale.edu/downloads/ epi2020report20200911.pdf

Wendling, Z. A., Emerson, J. W., Esty, D. C., Levy, M. A., de Sherbinin, A., et al. (2018). Environmental Performance Index. Yale Center for Environmental Law \& Policy. https:/epi.yale.edu/downloads/ epi2018reportv06191901.pdf

Willox, A. C., Stephenson, E., Allen, J., Bourque, F., Drossos, A., Elgarøy, S., et al. (2015). Examining relationships between climate change and mental health in the Circumpolar North. Regional Environmenatl Change. https://doi.org/10.1007/s10113-014-0630-z

World Bank Group (2017). World Development Indicators | Data. https://data.worldbank.org/products/ wdi

World Health Organization (2015). WHO calls for urgent action to protect health from climate changesign the call. https://www.who.int/globalchange/global-campaign/cop21/en/.

World Health Organization (2016). Deaths attributable to the environment, data by country. https://apps. who.int/gho/data/node.main.162?lang=en

World Health Organization (2019). Children: Reducing mortality. https://www.who.int/news-room/factsheets/detail/children-reducing-mortality

World Health Organization (2020). Global health observatory data. https://www.who.int/gho/phe/ outdoor_air_pollution/exposure/en/\#: :text=In\%20urban\%20areas\%2C\%20the\%20mean, 10\% 20\% CE\%BCm\%20or\%20less\%20(PM10)

World Meterological Organization. (2020). WMO statement on the state of the global climate in 2019. WMO-No. 1248. https://library.wmo.int/doc_num.php?explnum_id=10211

Zimmerman, C., \& Kiss, L. (2017). Human trafficking and exploitation: A global health concern. PLoS Medicine, 14(11), e1002437. https://doi.org/10.1371/journal.pmed.1002437

Publisher's Note Springer Nature remains neutral with regard to jurisdictional claims in published maps and institutional affiliations. 